\title{
Diagnosis \& Management of Iron Deficiency Anemia via Parental Iron
}

\author{
Iqbal MS ${ }^{1}$, Ahmed $\mathrm{MS}^{2^{*}}$, Ogras $\mathrm{TT}^{3}$, Ullah $\mathrm{S}^{4}$, Asif $\mathrm{JH}^{1}$ and Keshavarzi $\mathrm{F}^{5}$ \\ ${ }^{1}$ Department of Environmental System Analysis, Wageningen University, Netherlands; ${ }^{2}$ Department of \\ Bioinformatics and Biotechnology, International Islamic University, Islamabad, Pakistan; ${ }^{3}$ TUBITAK Marmara \\ Research Centre, Genetic Engineering \& Biotechnology Institute, Turkey; ${ }^{4}$ Department of Agricultural \\ Chemistry, KP Agricultural University Peshawar, Pakistan; ${ }^{5}$ Department of Biology, Sanandaj Branch, Islamic \\ Azad University, Sanandaj, Iran.
}

[Received: March 07, Accepted: September 16, 2012]

\begin{abstract}
All living things contain liquid inside their bodies which serves many functions like blood act as important connective tissue in transport of oxygen to all the cells similarly to excrete all the waste material from the cell to outside the body. Blood cells contain a red colored pigment which is called hemoglobin and its central portion is iron, when the level of haemoglobin falls in the body this condition is called anemia. To find the actual type of anemia different types of blood tests are conducted a person suffers. Most of the pregnant women suffer with the deficiency of iron. A study of such patients was conducted in Khyber Teaching Hospital Peshawar, and after collection of blood sample their test report indicate that most of the women were suffered with iron deficiency anemia. Total of seventy were taken into 2 groups A ( $\mathrm{n}=40$ ) and $B(n=30)$. For iron deficiency anemia intravenous and intra muscular iron therapy was compared based on Hemoglobin $(\mathrm{Hb})$ level Group A received intra venous iron ( 2 ampoules/alternate day), while Group B received intra muscular iron (1 ampoules/day). The data was recorded for group A $(\mathrm{Hb}=8.0 \pm 1.1 \mathrm{~g} / \mathrm{dl})$ at 15 days interval whereas for group B $(\mathrm{Hb}=8.8 \pm 0.9 \mathrm{~g} / \mathrm{dl})$ once prior to delivery. Group A showed an average rise of hemoglobin $2.5 \mathrm{~g} / \mathrm{dl}$ with mean value of $10.8 \mathrm{~g} / \mathrm{dl}$. On the other hand Group B indicated an increase of hemoglobin 1.4 $\mathrm{g} / \mathrm{dl}$ with mean of $10.2 \mathrm{~g} / \mathrm{dl}$ target hemoglobin level $(11 \mathrm{~g} / \mathrm{dl})$ was achieved $87 \%$ in group A and only $25 \%$ by group B. It was concluded that Intravenous therapy was safe, convenient and more effective than intramuscular iron therapy, in treating iron deficiency anemia.
\end{abstract}

Keywords: Intravenous, Intramuscular, Hemoglobin

\section{INTRODUCTION}

Iron is one of the essential mineral nutrients iron also serves as oxygen carrier and catalyst for oxygenation, hydroxylation and other metabolic processes $^{[1]}$. In the first stage of iron deficiency, iron stores are depleted without declining the iron levels in the blood. In the second stage, normal blood formation takes place but metabolism at the cellular level is affected, which lead to adverse effects on the nervous system, physical performance, intellectual capacity and immune system ${ }^{[2]}$. Final stage of iron deficiency results in conditions called hypo chromic and microcytic anemia.

In western communities 2-3\% of non-pregnant women are suffering from IDA ${ }^{[3]}$. While in developing countries IDA is common in pregnant women. The basic reason is non-supplementation of iron where they need 700 to $1400 \mathrm{mg}$ of extra iron for fetoplacental unit, red cell expansion and lactation. Studies have shown high risk of abortion and placental insufficiency leading to intrauterine growth restriction and death during sever IDA ${ }^{[4]}$. Other possible factors which are contributing in the development of IDA are mal-absorption (nutritional), women infestation, malaria and deficiency of vitamin C, Vitamin $\mathrm{B}_{12}$, Follic acid etc ${ }^{[5]}$.

During pregnancy Iron is supplemented through injection. Intra venus and intra muscular approach are mostly commonly used. The aim of the present study was to compare the percentage of patients who achieved the target hemoglobin i.e. $11 \mathrm{~g} / \mathrm{dl}$ through these two techniques at the time of delivery in the study groups ${ }^{[5]}$.

\section{MATERIALS AND METHODS}

Blood sample of 70 pregnant women were collected. The samples were further divided to carry out their test using different available techniques. The tests were included:

1) Hemoglobin with target cell: the hemoglobin was recorded in both group A \& B at different time periods.

2) Serum ferritin, pack cell volume, complete blood count $(\mathrm{CBC})$ : the detail is mentioned in table-2.

From the $\mathrm{Hb}$ tests of the patients their mean $\mathrm{Hb}$ level was recorded as 7 to $9 \mathrm{~g} / \mathrm{dl}$. The conformational tests also helped in excluding the patients having other causes of anemia like Thalassemia, B12 deficiency, Folic Acid deficiency.

History was taken carefully from the patients so that to monitor their hypersensitivity to iron dosage and to avoid any major side effects. The selected patients were divided into two groups A \& B, consisting 40 \& 30 patients respectively. Group A was provided 
with I.V iron while group B was administered I.M Iron.

Table-1 concentration of formed element of blood gram per deciliter

\begin{tabular}{lll}
\hline Duration & & Hemoglobin \\
& & \\
\hline Days & Group A & Group B \\
0 & $8.8 \pm 1.1 \mathrm{~g} / \mathrm{dl}$ & $8.8 \pm 0.9 \mathrm{~g} / \mathrm{dl}$ \\
Day $15^{\text {th }}$ & $9.5+0.5 \mathrm{~g} / \mathrm{dl}$ & $8.9+0.2 \mathrm{~g} / \mathrm{dl}$ \\
Day $30^{\text {th }}$ & $10.2+0.8 \mathrm{~g} / \mathrm{dl}$ & $9.0+0.4 \mathrm{~g} / \mathrm{dl}$ \\
${\text { Day } 50^{\text {th }}}_{\text {Prior to delivery }}$ & $11.5+0.6 \mathrm{~g} / \mathrm{dl}$ & $9.3+0.5 \mathrm{~g} / \mathrm{dl}$ \\
\hline
\end{tabular}

After that Intra-venous therapy was given twice or thrice in a week in infusion form while Intra muscular therapy was given in the form of daily or alternate day injection ( $2 \mathrm{ml} /$ injection). Both the therapies were started with sensitivity dose. Test dose of I.V. iron is 2 inj diluted in $100 \mathrm{ml} 0.9 \% \mathrm{NaCl}$ solution and $25 \mathrm{ml}$ of this infusion is used as test dose for 25 minutes at the rate of 12 drops per minute ${ }^{[2]}$. Adverse effects of the doses were observed with the following conditions:

Table-2 Responses of Injectable iron sorbitol given to 30 patients and injection Iron Sucrose Complexes to 40 patients. formed element of blood total number of the patients presenting in our data in six months were 3205, total number of admitted cases in these six months were 745 , out of these 490 were obstetrics department and rest were in the gynecology department. 190 patients had anemia. 70 patients were selected for the injectable iron therapy, iron sorbitol was administrated to 30 patients and rest was on the iron sucrose complex.

Group A was administered with intra venous iron and group B was given intra muscular iron. Depot irons of $500 \mathrm{mg}$ were given as additional to replenish the iron stores. Anemia is one of the commonest medical disorders, which occurs during pregnancy in developing countries. It increases the risk of maternal death to $20 \%$ and in another $20 \%$ it is a predisposing factor ${ }^{[6]}$. Hemoglobin and Hematocrit begin to rise after three days but the optimal response is achieved in three weeks ${ }^{[7]}$.

During pregnancy there is great demand for iron to meet the requirement for RBC mass expansion in the mother, fetus and placental blood and blood loss at delivery in addition to increased occult gastrointestinal blood loss ${ }^{[8]}$.

Iron demand is to be fulfilled in these cases, Malabsorption and increased demand in pregnancy may be one reason for iron supplementation. Though iron absorption may be adequate in healthy women

\begin{tabular}{lll}
\hline Response of Therapy & Iron Sucrose Complex & Iron Sorbitol \\
\hline $\begin{array}{l}\text { Hemoglobin level } \\
\begin{array}{l}\text { Days required for Hb } \\
\text { correction mean }\end{array}\end{array}$ & 11.0 & 11.0 \\
$\mathrm{MCV}$ & 21 & 21 \\
$\mathrm{~S} /$ Ferritin & 75 & 74 \\
Side Effects & 15.2 & 15.1 \\
& $\begin{array}{l}\text { Nausia in one patient, } \\
\text { Generalized oedema } \\
\text { resolved in 3 hrs }\end{array}$ & $\begin{array}{l}\text { Pain and Pigmentation in } \\
\text { most of the patients (cases) }\end{array}$ \\
$\begin{array}{l}\text { Rupees per Course } \\
\text { No of ampules required to } \\
\text { increase the Hb one gram }\end{array}$ & 2 ampules & $170+-51$ \\
$\begin{array}{l}\text { Number of visits required for } \\
\text { injectable therapy }\end{array}$ & One to three & $12+-3$ \\
$\begin{array}{l}\text { Admission required for the } \\
\text { therapy }\end{array}$ & Yes /Day care & Ten to fifteen \\
\hline
\end{tabular}

${ }^{[9]}$. It is far below the iron requirement of an iron depleted of deficient pregnant women.

- Mild some awareness of the symptoms, and easily tolerated.

- Moderate symptoms causing enough discomfort to interfere normal activity.

- Sever, significantly side effect with respect to the patient.

- Serious life threatening / permanently disabling.

\section{RESULTS AND DISCUSSION}

A temporary anemia during pregnancy may occur. The factor involved in its causation includes increased demand and dietary, especially folate, vit B12 and iron. Table-1 shows the concentration of
Injectable iron sorbital was given to 30 patients and injection Iron Sucrose Complex to 40 patients. Responses were calculated as shown in the Table-2.

It has been observed that daily iron loss occur is about 2-3mg / day in normal healthy female while in pregnancy this demand is increased to meet the requirement of fetus. The iron losses must be balanced by the intake of iron in the food. The average intake of iron in developed countries is

\section{CONCLUSION}


around $10-15 \mathrm{mg} /$ day and in normal condition only $2-3 \%$ is absorbed orally[7]. Intra venues iron is safe more effective and user friendly in the treatment of iron deficiency. It's cost effective when its effectiveness is compared with that of alternate iron therapies and by eliminating the need of blood transfusion, especially in sever iron deficiency anemia in pregnancy.

Injectable iron sorbitol is already in practice since 25 years after the failure of Injection Imferon, because of anaphylactic reaction. Our patients are more worried about the pain due to the injection which is to be given repeatedly while they don't bother about the pigmentation contrary to the other countries ${ }^{[10]}$. Majority of our population is illiterate, unemployed and resident of villages. These factors individually and cumulatively effect our decisions in the management plans of different patients.

\section{ACKNOWLEDGEMENTS}

The study was performed with the support of Khyber Teaching Hospital Peshawar, Pakistan. The author is heartily thankful to Muhammad Saad Ahmed \& Tijen Talas Ogras, whose technical guidance and support explore the author's skills.

\section{REFERENCES}

1) 1 Sash L and Donna C (1994). A demographic portrait of South \& South East Asia. Washington D.C: Population Reference Bureau. 10-16.

2) Worwood M and Ferritin S (1980). In: Cook JD, ed. Iron. New York: Churchill Livingstone.
(Chanarin I, Beutler E, Brown EB, Jacobs A, eds. Methods in hematology; 1: 59-89.

3) Hallberg L, Hogdahi AM, Nilsson L and Rybo G (1966). Menstrual Blood Loss, a population study variation at different ages and attempts to define normality. Acta Obstet. Gynaecolo. Scand. 45:325-351.

4) Bhatt RB, Joshi SK and Shah MC (1966) Total dose of intramuscular infusion of iron-dextran (imferon) in severe anemia. AM.J. Obstet. \& Gynaeecol. 94:1098-1103.

5) Al-Momin AK, Haraib SO, Mitwalli AH, AlWakeel $J$ and Abu-Aiha $H$ (1986). Intravenous Iron Sucrose Complex and haemodialysis patients receiving r-Hu EPO. Saudi J. Kidney Transplant. 5: 168-172.

6) Sogbanmu MO (1986). Anemia of pregnancy treated with total infusion of Iron Polymaltose complex. Tefferol current therapy. Clin Exp. 21:149-155.

7) Breymann C, Fibach E and Visca E (1999) J. Maternal and Fetal Medicine 8:1-7.

8) Al-Momin, Al-Meshari AA et al (1996). Intra venous iron sucrose complex in the treatment of iron deficiency anemia during pregnancy. Eur. J. Obst. Gynaecol. And Reproductive biology. 69: 121-124.

9) Johnson CA (1999). Intravenous iron Products. ANNA J. 26:522-524.

10) Idjradinata P and Polbtt E (1993). Reversal of developmental delays in iron deficient anemic infants treated with iron. Lancet. 314: 1-4. 